\title{
KESIAPAN BELTIM DALAM MENGHADAPI MEA
}

\author{
Agus Triyono \\ STAIN Syaikh Abdurrahman Siddik Bangka Belitung
}

\begin{abstract}
On the investment side, the MEA creates a climate that supports the entry of Foreign Direct Investment (FDI) that can stimulate economic growth through technological development, employment field creation, human capital development and easier access to world markets. With the presence of this MEA event, Indonesia has an opportunity to take advantage of domestic economies of scale as a basis to gain profit. However, Indonesia still has many challenges and risks that will arise if the MEA has been fully implemented. East Belitung Regency as one of the areas that provide an advantage for the Province of Bangka Belitung Islands began to show the identity as a region ready to welcome MEA, but the question arises as to what challenges will be faced. The challenges faced by Beltim starting from the low utilization of human resources, the Beltim Government has not issued its own policies on employment and the increasing educated unemployment who are unable to be absorbed by the formal job market.
\end{abstract}

Keyword: Beltim and MEA.

\section{A. Masyarakat Ekonomi ASEAN dan Belitung Timur}

Siapkah anda menghadapi persaingan di tahun 2015? Sudah seharusnya kita bersiap menghadapi ketatnya persaingan di tahun 2015 mendatang. Indonesia dan negara-negara di wilayah Asia Tenggara akan membentuk sebuah kawasan yang terintegrasi yang dikenal sebagai Masyarakat Ekonomi ASEAN (MEA). MEA merupakan bentuk realisasi dari tujuan akhir integrasi ekonomi di kawasan Asia Tenggara. 
Terdapat empat hal yang akan menjadi fokus MEA ${ }^{1}$ pada tahun 2015 yang dapat dijadikan suatu momentum yang baik untuk Indonesia. Pertama, negara-negara di kawasan Asia Tenggara ini akan dijadikan sebuah wilayah kesatuan pasar dan basis produksi. Dengan terciptanya kesatuan pasar dan basis produksi maka akan membuat arus barang, jasa, investasi, modal dalam jumlah yang besar, dan skilled labour menjadi tidak ada hambatan dari satu negara ke negara lainnya di kawasan Asia Tenggara.

Kedua, MEA akan dibentuk sebagai kawasan ekonomi dengan tingkat kompetisi yang tinggi, yang memerlukan suatu kebijakan yang meliputi competition policy, consumer protection, Intellectual Property Rights (IPR), taxation, dan E-Commerce. Dengan demikian, dapat tercipta iklim persaingan yang adil; terdapat perlindungan berupa sistem jaringan dari agen-agen perlindungan konsumen; mencegah terjadinya pelanggaran hak cipta; menciptakan jaringan transportasi yang efisien, aman, dan terintegrasi; menghilangkan sistem Double Taxation, dan; meningkatkan perdagangan dengan media elektronik berbasis online.

Ketiga, MEA pun akan dijadikan sebagai kawasan yang memiliki perkembangan ekonomi yang merata, dengan memprioritaskan pada Usaha Kecil Menengah (UKM). Kemampuan daya saing dan dinamisme UKM akan ditingkatkan dengan memfasilitasi akses mereka terhadap informasi terkini, kondisi pasar, pengembangan sumber daya manusia dalam hal peningkatan kemampuan, keuangan, serta teknologi.

Keempat, MEA akan diintegrasikan secara penuh terhadap perekonomian global. Dengan dengan membangun sebuah sistem untuk meningkatkan koordinasi terhadap negara-negara anggota. Selain itu, akan ditingkatkan partisipasi negara-negara di kawasan Asia Tenggara pada jaringan pasokan global melalui pengembangkan paket bantuan teknis kepada negara-negara

1 http://www.academia.edu/9060383/masyarakat_ekonomi_ASEAN_2015_MEA_2015, diakses tanggal 21 November 2017. 
Anggota ASEAN yang kurang berkembang. Hal tersebut dilakukan untuk meningkatkan kemampuan industri dan produktivitas sehingga tidak hanya terjadi peningkatkan partisipasi mereka pada skala regional namun juga memunculkan inisiatif untuk terintegrasi secara global.

Berdasarkan ASEAN Economic Blueprint, MEA menjadi sangat dibutuhkan untuk memperkecil kesenjangan antara negara-negara ASEAN dalam hal pertumbuhan perekonomian dengan meningkatkan ketergantungan anggota-anggota didalamnya. MEA dapat mengembangkan konsep metanasional dalam rantai suplai makanan, dan menghasilkan blok perdagangan tunggal yang dapat menangani dan bernegosiasi dengan eksportir dan importir non-ASEAN.

Bagi Indonesia sendiri, MEA akan menjadi kesempatan yang baik karena hambatan perdagangan akan cenderung berkurang bahkan menjadi tidak ada. Hal tersebut akan berdampak pada peningkatan eskpor yang pada akhirnya akan meningkatkan GDP Indonesia. Di sisi lain, muncul tantangan baru bagi Indonesia berupa permasalahan homogenitas komoditas yang diperjualbelikan, contohnya untuk komoditas pertanian, karet, produk kayu, tekstil, dan barang elektronik (Santoso, 2008). Dalam hal ini competition risk akan muncul dengan banyaknya barang impor yang akan mengalir dalam jumlah banyak ke Indonesia yang akan mengancam industri lokal dalam bersaing dengan produk-produk luar negri yang jauh lebih berkualitas. Hal ini pada akhirnya akan meningkatkan defisit neraca perdagangan bagi Negara Indonesia sendiri.

Pada sisi investasi, kondisi ini dapat menciptakan iklim yang mendukung masuknya Foreign Direct Investment (FDI) yang dapat menstimulus pertumbuhan ekonomi melalui perkembangan teknologi, penciptaan lapangan kerja, pengembangan sumber daya manusia (human capital) dan akses yang lebih mudah kepada pasar dunia. Meskipun begitu, kondisi tersebut dapat memunculkan exploitation risk. Indonesia masih memiliki tingkat regulasi yang 
kurang mengikat sehingga dapat menimbulkan tindakan eksploitasi dalam skala besar terhadap ketersediaan sumber daya alam oleh perusahaan asing yang masuk ke Indonesia sebagai negara yang memiliki jumlah sumber daya alam melimpah dibandingkan negara-negara lainnya. Tidak tertutup kemungkinan juga eksploitasi yang dilakukan perusahaan asing dapat merusak ekosistem di Indonesia, sedangkan regulasi investasi yang ada di Indonesia belum cukup kuat untuk menjaga kondisi alam termasuk ketersediaan sumber daya alam yang terkandung.

Dari aspek ketenagakerjaan, terdapat kesempatan yang sangat besar bagi para pencari kerja karena dapat banyak tersedia lapangan kerja dengan berbagai kebutuhan akan keahlian yang beraneka ragam. Selain itu, akses untuk pergi keluar negeri dalam rangka mencari pekerjaan menjadi lebih mudah bahkan bisa jadi tanpa ada hambatan tertentu. MEA juga menjadi kesempatan yang bagus bagi para wirausahawan untuk mencari pekerja terbaik sesuai dengan kriteria yang diinginkan. Dalam hal ini dapat memunculkan risiko ketenagakarejaan bagi Indonesia. Dilihat dari sisi pendidikan dan produktivitas Indonesia masih kalah bersaing dengan tenaga kerja yang berasal dari Malaysia, Singapura, dan Thailand serta fondasi industri yang bagi Indonesia sendiri membuat Indonesia berada pada peringkat keempat di ASEAN (Republika Online, 2013).

Dengan hadirnya ajang MEA ini, Indonesia memiliki peluang untuk memanfaatkan keunggulan skala ekonomi dalam negeri sebagai basis memperoleh keuntungan. Namun demikian, Indonesia masih memiliki banyak tantangan dan risiko-risiko yang akan muncul bila MEA telah diimplementasikan. Oleh karena itu, para risk professional diharapkan dapat lebih peka terhadap fluktuasi yang akan terjadi agar dapat mengantisipasi risiko-risiko yang muncul dengan tepat. Selain itu, kolaborasi yang apik antara otoritas negara dan para pelaku usaha diperlukan, infrastrukur baik secara fisik dan sosial(hukum dan kebijakan) perlu dibenahi, serta perlu adanya 
peningkatan kemampuan serta daya saing tenaga kerja dan perusahaan di Indonesia. Jangan sampai Indonesia hanya menjadi penonton di negara sendiri di tahun 2015 mendatang.

Tersedianya lapangan/kesempatan kerja baru untuk mengatasi peningkatan penawaran tenaga kerja merupakan salah satu target yang harus dicapai dalam pembangunan ekonomi daerah. Upaya tersebut dapat diwujudkan melalui peningkatan pertumbuhan ekonomi khususnya investasi langsung (direct investment) pada sektor-sektor yang bersifat padat karya, seperti konstruksi, infrastruktur maupun industri pengolahan. Sementara pada sektor jasa, misalnya melalui perdagangan maupun pariwisata. Tenaga kerja adalah orang yang siap masuk dalam pasar kerja sesuai dengan upah yang ditawarkan oleh penyedia pekerjaan. Jumlah tenaga kerja dihitung dari penduduk usia produktif (umur 15 thn-65 thn) yang masuk kategori angkatan kerja (labourforce).

Kondisi di negara berkembang pada umumnya memiliki tingkat pengangguran yang jauh lebih tinggi dari angka resmi yang dikeluarkan oleh pemerintah. Hal ini terjadi karena ukuran sektor informal masih cukup besar sebagai salah satu lapangan nafkah bagi tenaga kerja tidak terdidik. Sektor informal tersebut dianggap sebagai katup pengaman bagi pengangguran.

Angka resmi tingkat pengangguran umumnya menggunakan indikator pengangguran terbuka, yaitu jumlah angkatan kerja yang secara sungguhsungguh tidak bekerja sama sekali dan sedang mencari kerja pada saat survei dilakukan. Sementara yang setengah pengangguran dan penganggur terselubung tidak dihitung dalam angka pengangguran terbuka, karena mereka masih menggunakan waktu produktifnya selama seminggu untuk bekerja meskipun tidak sampai 35 jam penuh.

Sumber data ketenagakerjaan seperti instansi yang bertanggung jawab dibidang ketenagakerjaan yang berada di daerah baik Propinsi maupun Kabupaten/Kota tidak pernah lagi mau mengirim data dan informasi ke pusat 
.Kondisi ini telah mempengaruhi keberadaan data dan informasi ketenagakerjaan, yang pada akhirnya data dan informasi ketenagakerjaan yang dipergunakan saat ini masih bertumpu pada data dan informasi ketenagakerjaan yang bersifat makro. Data dan informasi ketenagakerjaan makro tersebut, sampai saat ini belum mampu untuk menjawab berbagai tantangan dan masalah ketenaga-kerjaan yang dihadapi.

Kabupaten Belitung Timur merupakan salah satu wilayah administratif dari tujuh wilayah administratif yang ada di Provinsi Kepulauan Bangka Belitung. Kabupaten Belitung Timur dibentuk berdasarkan Undang-Undang Nomor 5 Tahun 2003 tentang pembentukan Kabupaten Bangka Barat, Bangka Tengah, Bangka Selatan, dan Belitung Timur.

Sebagai kabupaten yang baru genap berusia 13 tahun (bersama Kabupaten Bangka Barat, Bangka Tengah, dan Bangka Selatan) tentu Kabupaten Belitung Timur perlu melakukan akselerasi pembangunan di segala aspek agar tidak ketinggalan jauh dari wilayah lain dalam wilayah Negara Kesatuan Republik Indonesia yang relatif sudah berdiri lebih lama, atau paliing tidak, dapat mendekati capaian pembangunan di kabupaten/kota yang telah lebih dulu ada di wilayah provinsi Kepulauan Bangka Belitung.

Sejak Provinsi Kepulauan Bangka Belitung memiliki daerah Kawasan Ekonomi Khusus (KEK) di Tanjung Kelayang dengan diterbitkannya UU No 39 tahun 2009 tentang Kawasan Ekonomi Khusus, PP No 6 tahun 2016 tentang Kawasan Ekonomi Khusus Tanjung Kelayang. KEK yang ditetapkan sebagai KEK Pariwisata ini memiliki keunggulan geostrategis, yaitu terletak antara Indonesia dan negara ASEAN yang merupakan target captive market. KEK Tanjung Kelayang termasuk ke dalam 10 destinasi pariwisata prioritas memiliki objek wisata bahari dengan pantai berpasir putih dan panorama yang eksotis. Pantai yang dihiasi batuan granit raksasa merupakan ciri khas dari pantai di kawasan ini. Kawasan ini berdekatan dengan pulau-pulau kecil disekitarnya yang juga memiliki pesonanya tersendiri. Dengan total luas wilayah sebesar 
324,4 Ha, KEK Tanjung Kelayang memiliki konsep pengembangan pariwisata, yaitu "Socially and Environmentally Responsible Development and Cultural Preservation". Dengan konsep pengembangan pariwisata berkelanjutan dan berwawasan lingkungan, KEK ini diharapkan mampu menarik investasi sebesar Rp 20 triliun hingga 2025, serta mendatangkan 59.000 wisatawan per tahun dengan nilai ekonomi Rp 751,4 miliar per tahun pada saat KEK ini sudah beroperasi penuh².

Penetapan KEK Tanjung Kelayang akan memberikan efek domino yang cukup besar bagi daerah sekitarnya, namun hal ini juga membutuhkan persiapan yang cukup banyak, termasuk tenaga kerja yang akan menunjang ketercapaian suksesnya KEK ini. Pasokan tenaga kerja diharapkan akan menyerap sumber daya lokal yang dapat memenuhi syarat minimal kompetensi, mengingat berbagai kondisi yang terdapat di pulau Belitung. Dengan mengandalkan lingkungan sebagai modal utama, perlu dukungan pihak-pihak terkait untuk menjaga keberlangsungannya dan komitmen penduduk lokal dalam meningkatkan kesadaran bahwa lingkungan merupakan sumber mata pencarian. Akan menjadi pertanyaan besar, bagaimana profil penduduk usia kerja di kabupaten Belitung Timur , bagaimana kesiapan daerah dalam mempersiapkanya tenaga kerja, dan apa saja tantangan yang dihadapi saat menghadapi MEA dan KEK. Tenaga pariwisata merupakan salah satu dari delapan bidang ketenagakerjaan yang disepakati dalam MEA.

\section{B. Ketenagakerjaan dan Masyarakat Ekonomi ASEAN}

Kesempatan kerja merupakan hubungan antara angkatan kerja dengan kemampuan penyerapan tenaga kerja. Pertambahan angkatan kerja harus diimbangi dengan investasi yang dapat menciptakan kesempatan kerja. Dengan demikian, dapat menyerap pertambahan angkatan kerja.

\footnotetext{
${ }^{2}$ Data dari Website kek.go.id/kawasan/tanjung-kelayang, diakses 27 November 2017.
} 
Dalam ilmu ekonomi, kesempatan kerja berarti peluang atau keadaan yang menunjukkan tersedianya lapangan pekerjaan sehingga semua orang yang bersedia dan sanggup bekerja dalam proses produksi dapat memperoleh pekerjaan sesuai dengan keahlian, keterampilan dan bakatnya masing-masing. Kesempatan Kerja (demand for labour) adalah suatu keadaan yang menggambarkan/ketersediaan pekerjaan (lapangan kerja untuk diisi oleh para pencari kerja). Sumarsono ${ }^{3}$ mendefinisikan kesempatan kerja sebagai lapangan pekerjaan yang sudah di duduki (employment) dan masih lowongan (vacancy). Dengan demikian kesempatan kerja dapat diartikan sebagai permintaan atas tenaga kerja.

Menurut Soemitro Djojohadikusumo, tenaga kerja adalah semua orang yang bersedia dan sanggup bekerja, termasuk mereka yang menganggur meskipun bersedia dan sanggup bekerja dan mereka yang menganggur terpaksa akibat tidak ada kesempatan kerja4. Sedangkan menurut UU No. 13 tahun 2003 tentang Ketenagakerjaan dalam BAB I Pasal 1, yang dimaksud dengan Ketenagakerjaan adalah segala hal yang berhubungan dengan tenaga kerja pada waktu sebelum, selama, dan sesudah masa kerja. Tenaga kerja adalah setiap orang yang mampu melakukan pekerjaan guna menghasilkan barang dan/atau jasa baik untuk memenuhi kebutuhan sendiri maupun untuk masyarakat. Melihat dari berbagai definisi di atas, tenaga kerja merupakan manusia produktif yang memiliki pengetahuan dan ketrampilan. Untuk mendaptakan pengetahuan, pada umumnya diperoleh dari lembaga pendidikan formal, sedangkan ketrampilan pada umumnya diperoleh dari lembaga pendidikan nonformal seperti Balai Latihan Kerja, Lembaga Pelatihan Komputer, dan lainnya. Dengan tingkat pendidikan yang tinggi dan ditambah

3 Sonny Sumarsono. Ekonomi Manajemen Sumber Daya Manusia dan Ketenaga kerjaan. (Jogyakarta : Graha Ilmu, 2003), hal 41

${ }^{4}$ Sumitro Djojohadikusumo, Dasar Teori Ekonomi Pertumbuhan dan Pembangunan, (Jakarta : Bagian Penerbitan : LP3ES, 1987). 
ketrampilan dari lembaga pelatihan akan memberikan nilai tambah yang tinggi. Dimana dalam BAB V Pasal 9, Pelatihan kerja diselenggarakan dan diarahkan untuk membekali, meningkatkan, dan mengembangkan kompetensi kerja guna meningkatkan kemampuan, produktivitas, dan kesejahteraan.

\section{Konsep Angkatan Kerja}

Konsep dan definisi angkatan kerja yang digunakan mengacu kepada The Labor Force Concept yang disarankan oleh International Labor Organization (ILO) ${ }^{5}$. Konsep ini membagi penduduk menjadi penduduk usia kerja dan penduduk bukan usia kerja, penduduk usia kerja (digunakan 15 tahun ke atas) dan penduduk bukan usia kerja (kurang dari 15 tahun). Selanjutnya penduduk usia kerja dibagi menjadi dua kelompok, yaitu angkatan kerja dan bukan angkatan kerja. Khusus untuk angkatan kerja meliputi:

1. Bekerja

2. Punya pekerjaan tapi sementara tidak bekerja

3. Mencari pekerjaan (pengangguran terbuka).

\section{D.Pemanfaatan Tenaga Kerja}

Masalah ketenagakerjaan yang paling menonjol sampai saat ini masih berkisar pada pengangguran. Tingkat pengangguran memang merupakan salah satu indikator perekonomian yang penting. Maka tidak mengherankan bila itu dijadikan permasalahan yang penting pula. Secara sederhana pengangguran disebabkan oleh dua hal yaitu banyaknya tenaga kerja dan atau sempitnya kesempatan kerja. Hal lain di belakang itu tentu saja tidak sederhana. Pada wilayah yang tingkat penganggurannya tinggi muncul masalah lain seperti penempatan tenaga kerja yang tidak sesuai dengan potensi serta latar belakangnya dan upah yang rendah.

5 Keadaan Angkatan Kerja di Indonesia/Labor Force Situation in Indonesia, Badan Pusat Statistik, 2013, hal xiii 
Dalam rangka pemerataan sering juga terjadi kerja dengan jam yang kecil dan tentu saja upah yang kecil pula. Masalah seperti perlakuan terhadap pekerja yang tidak semestinya bukan tidak mungkin pula. Secara umum bisa muncul masalah underutilization, kurang termanfaatkannya tenaga kerja. Gejala ini biasanya diikuti dengan ketidakpuasan pekerja dan usaha mencari kerja lain yang Iebih sesuai. Kurang pemanfaatan tenaga kerja merupakan gejala yang umum. Ini tidakhanya terjadi di negara-negara berkembang dengan tingkat pengangguran yangsangat tinggi tetapi juga di negara-negara maju. Perbedaannya pada spesifikasi penyebab dan proporsi. Di negara-negara maju penyebab utamanya adalah terlalu tinggi tingkat pendidikan atau over edukasi dan deskilling (O'Brien, 1986).

Tingkat pendidikan yang tinggi berarti memiliki kemampuan yang tinggi. Bila tidak termanfaatkan kemampuan itu tidak termanifestasikan dan berkembang, bahkan bisa susut dan hilang. Tingkat pendidikan yang tinggi juga meningkatkan aspirasi, keinginan memiliki otonomi dan variasi dalam kerja. Bila hal ini tidak tersalurkan dengan baik maka efek negatif akan muncul.Padahal di sisi lain tidak seluruh pekerjaan menuntut pandidikan yang tinggi.Untuk menjadi operator mesin misalnya, tamatan sekolah menengah pertama bisa mengerjakannya. Anehnya ada kecenderungan menerima pekerjaan yang tingkat pendidikannya lebih tinggi tanpa melihat pekerjaan.

\section{E. Sekilas Masyarakat Ekonomi ASEAN (MEA)}

Pembentukan MEA dilandaskan pada empat pilar. Pertama, menjadikan ASEAN sebagai pasar tunggal dan pusat produksi. Kedua, menjadi kawasan ekonomi yang kompetitif. Ketiga, menciptakan pertumbuhan ekonomi yang seimbang, dan pilar terakhir adalah integrasi ke ekonomi global. Penyatuan ini ditujukan untuk meningkatkan daya saing kawasan, mendorong pertumbuhan ekonomi, menekan angka kemiskinan dan untuk meningkatkan standar hidup masyarakat ASEAN. Integrasi ini diharapkan akan membangun perekonomian 
ASEAN serta mengarahkan ASEAN sebagai tulang punggung perekonomian Asia.

Dengan dimulainya MEA maka setiap negara anggota ASEAN harus meleburkan batas teritori dalam sebuah pasar bebas. MEA akan menyatukan pasar setiap negara dalam kawasan menjadi pasar tunggal. Sebagai pasar tunggal, arus barang dan jasa yang bebas merupakan sebuah kemestian. Selain itu negara dalam kawasan juga diharuskan membebaskan arus investasi, modal dan tenaga terampil. Arus bebas barang, jasa, investasi, modal dan tenaga kerja tersebut tak pelak menghadirkan kekhawatiran tersendiri bagi beberapa pihak. Dalam hal ini pasar potensial domestik dan lapangan pekerjaan menjadi taruhan. Sekedar bahan renungan, indek daya saing global Indonesia tahun 2013-2014 (rangking 38) yang jauh di bawah Singapura (2), Malaysia (24), Brunai Darussalam (26) dan satu peringkat di bawah Thailand (37). Di sisi lain coba kita lihat populasi Indonesia yang hampir mencapai 40\% populasi ASEAN. Sebuah pasar yang besar tapi tak didukung daya saing yang maksimal. Jangan sampai Indonesia mengulang dampak perdagangan bebas ASEAN China. Berharap peningkatan perekonomian malah kebanjiran produk China.

Di saat yang sama, MEA akan dapat mengatasi kesenjangan pada pembangunan dan melakukan percepatan integrasi kepada negara Laos, Myanmar, VIetnam dan Kamboja lewat Initiative for ASEAN integration dan inisiatif dari regional yang lainnya. Adapun bentuk kerjasamanya ialah:

1. Pengembangan pada sumber daya manusia dan adanya peningkatan kapasitas

2. Pengakuan terkait kualifikasi profesional

3. Konsultasi yang lebih dekat terhadap kebijakan makro keuangan dan ekonomi.

4. Memiliki langkah-langkah dalam pembiayaan perdagangan.

5. Meningkatkan infrastruktur. 
6. Melakukan pengembangan pada transaksi elektronik lewat e-ASEAN.

7. Memperpadukan segala industri yang ada diseluruh wilayah untuk dapat mempromosikan sumber daerah.

8. Meningkatkan peran dari sektor swasta untuk dapat membangun MEA atau Masyarakat Ekonomi ASEAN.

\section{F. Dampak Positif Masyarakat Ekonomi ASEAN (MEA)}

1. Pada Sisi Perdagangan

Menurut Santoso pada tahun 2008 Bagi Indonesia sendiri, MEA akan menjadi kesempatan yang baik karena hambatan perdagangan akan cenderung berkurang bahkan menjadi tidak ada. Hal tersebut akan berdampak pada peningkatan eskpor yang pada akhirnya akan meningkatkan GDP Indonesia.

2. Pada Sisi Investasi

Kondisi ini dapat menciptakan iklim yang mendukung masuknya Foreign Direct Investment (FDI) yang dapat menstimulus pertumbuhan ekonomi melalui perkembangan teknologi, penciptaan lapangan kerja, pengembangan sumber daya manusia (human capital) dan akses yang lebih mudah kepada pasar dunia.

3. Pada Sisi Ketenagakerjaan

Terdapat kesempatan yang sangat besar bagi para pencari kerja karena dapat banyak tersedia lapangan kerja dengan berbagai kebutuhan akan keahlian yang beraneka ragam. Selain itu, akses untuk pergi keluar negeri dalam rangka mencari pekerjaan menjadi lebih mudah bahkan bisa jadi tanpa ada hambatan tertentu. MEA juga menjadi kesempatan yang bagus bagi para wirausahawan untuk mencari pekerja terbaik sesuai dengan kriteria yang diinginkan. Para tenaga kerja Indonesia juga dapat bekerja di negara anggota ASEAN dengan bebas dan sesuai dengan keterampilan yang dimilikinya. 


\section{G. Dampak Negatif Masyarakat Ekonomi ASEAN (MEA)}

\section{Pada Sisi Kompetisi}

Kompetisi akan muncul dengan banyaknya barang impor yang akan mengalir dalam jumlah banyak ke Indonesia yang akan mengancam industri lokal dalam bersaing dengan produk-produk luar negri yang jauh lebih berkualitas. Hal ini pada akhirnya akan meningkatkan defisit neraca perdagangan bagi Negara Indonesia sendiri.

2. Pada sisi Ekploitasi

Exploitation dengan skala besar terhadap ketersediaan sumber daya alam oleh perusahaan asing yang masuk ke Indonesia sebagai negara yang memiliki jumlah sumber daya alam melimpah dibandingkan negaranegara lainnya. Tidak tertutup kemungkinan juga eksploitasi yang dilakukan perusahaan asing dapat merusak ekosistem di Indonesia, sedangkan regulasi investasi yang ada di Indonesia belum cukup kuat untuk menjaga kondisi alam termasuk ketersediaan sumber daya alam yang terkandung.

3. Pada Sisi Ketenagakarejaan

Dampak negatif pada sisi ketenagakerjaan dapat dilihat dari sisi pendidikan dan produktivitas Indonesia masih kalah bersaing dengan tenaga kerja yang berasal dari Malaysia, Singapura, dan Thailand serta fondasi industri yang bagi Indonesia sendiri membuat Indonesia berada pada peringkat keempat di ASEAN. Menurut Media Indonesia, Kamis 27 Maret 2014, dengan adanya pasar barang dan jasa secara bebas tersebut akan mengakibatkan tenaga kerja asing dengan mudah masuk dan bekerja di Indonesia sehingga mengakibatkan persaingan tenaga kerja yang semakin ketat di bidang ketenagakerjaan. 


\section{H. Geografis Kabupaten Belitung Timur}

Secara geografis Kabupaten Belitung Timur terletak antara $107^{0} 45^{\prime}$ BT sampai $108^{0} 18^{\prime}$ BT dan $02^{0} 30^{\prime}$ LS sampai $03^{\circ} 15^{\prime}$ LS dengan luas daratan mencapai 250.691 ha atau kurang lebih 2.506,91 km². Kabupaten Belitung Timur di sebelah utara berbatasan dengan laut Cina Selatan, sebelah timur berbatasan dengan Selat Karimata, sebelah selatan berbatasan dengan laut Jawa, dan sebelah barat berbatasan dengan kabupaten Belitung6. Kabupaten Belitung Timur Dibentuk berdasarkan Undang-Undang Republik Indonesia Nomor 5 Tahun 2003 tentang Pembentukan Kabupaten Bangka Selatan, Kabupaten Bangka Tengah, Kabupaten Bangka Barat, dan Kabupaten Belitung Timur di Wilayah Provinsi Kepulauan Bangka Belitung. Undang-undang tersebut ditetapkan pada tanggal 25 Februari 2003 dalam sidang Dewan Perwakilan Rakyat Republik Indonesia.

Secara administratif Kabupaten Belitung Timur berbatasan langsung dengan Kabupaten Belitung di sebelah barat, Selat Karimata di timur, Laut China Selatan di utara dan Laut Jawa di sebelah selatan. Wilayah administrasi pemerintahan Kabupaten Belitung Timur terbagi ke dalam 7 kecamatan, yaitu Kecamatan Dendang, Kecamatan Simpang Pesak, Kecamatan Gantung, Kecamatan Simpang Renggiang, Kecamatan Manggar, Kecamatan Damar dan Kecamatan Kelapa Kampit. Pada tahun 2014 Kabupaten Belitung Timur terdiri dari 7 Kecamatan, 39 desa, 147 dusun dan 732 Rukun Tetangga (RT). Jumlah RT terbanyak masih terdapat di Kecamatan Manggar yang merupakan ibukota serta pusat pemerintahan Kabupaten Belitung Timur yaitu sebanyak 196 RT. Disusul Gantung sebanyak 147 RT, Kelapa Kampit 118 RT, Damar 88 RT, Dendang 77 RT, Simpang Renggiang 60 RT dan terakhir Simpang Pesak 46 RT7. Dengan luas wilayah 250.691 Ha, Kabupaten Belitung terbagi Kecamatan

\footnotetext{
${ }^{6}$ Data Dasar Kabupaten Belitung Timur Tahun 2013 badan Perencanaan Pembangunan Daerah Kabupaten Belitung Timur Tahun 2013

${ }^{7}$ http://belitungtimurkab.bps.go.id/belitungtimurdalamangka 2014
} 
Dendang dengan luas wilayah 362,20 km²; Kecamatan Simpang Pesak dengan luas 243,30 km²; Kecamatan Gantung dengan luas 546,30 km²; Kecamatan Simpang Renggiang dengan luas wilayah 390,70 km²; Kecamatan Manggar dan Kecamatan Damar 465,90 km² dan Kecamatan Kelapa Kampit dengan luas wilayah $498,51 \mathrm{~km}^{2}$.

Berikut peta wilayah Kabupaten Belitung Timur:

\section{Gambar 1}

\section{Peta Kabupaten Belitung Timur}

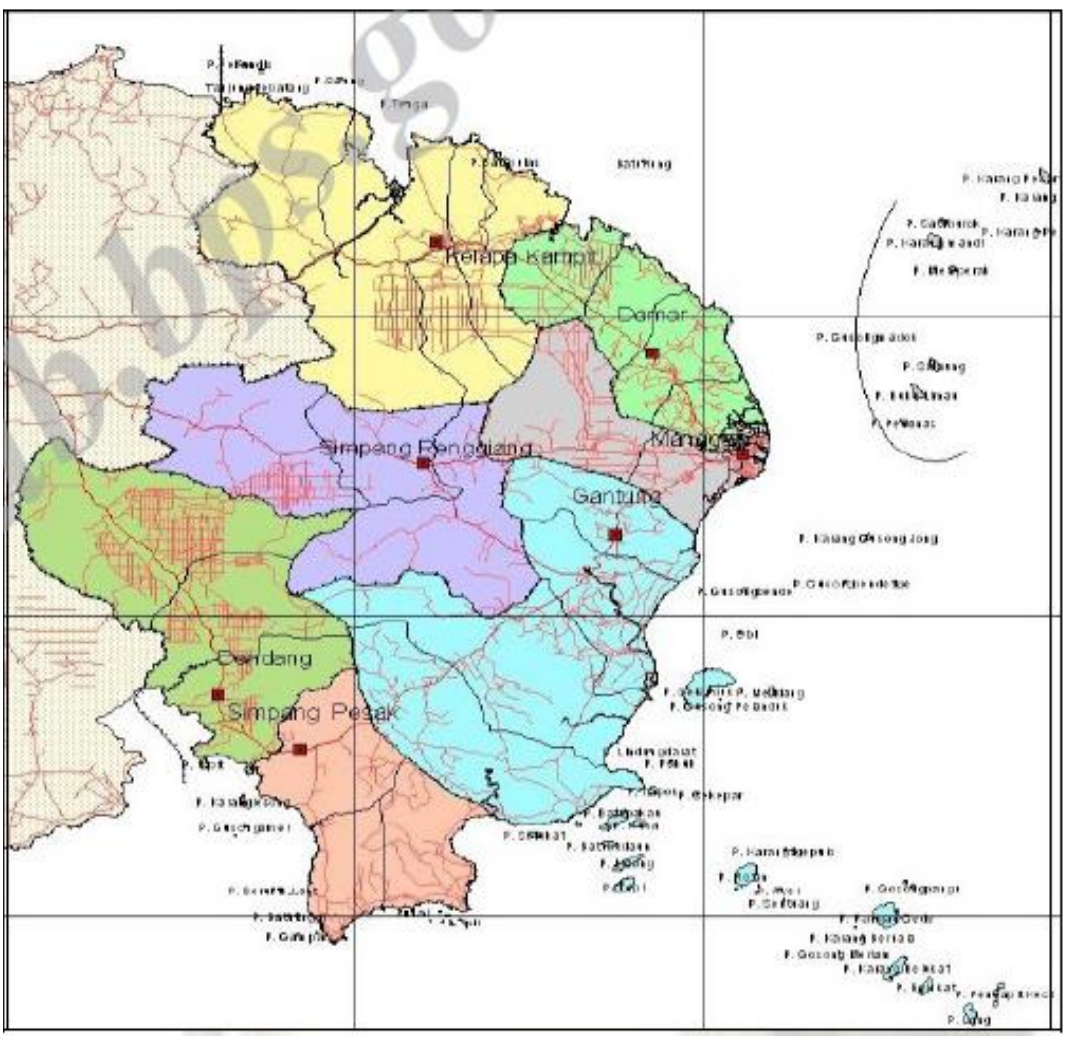

Sumber: Statistik Daerah Belitung Timur $2015^{8}$

\section{Penduduk}

Komposisi penduduk Kabupaten Belitung Timur berdasarkan jenis kelamin pada tahun 2014 masih didominasi oleh penduduk laki-laki dengan

${ }^{8}$ Badan Pusat Statistik Kabupaten Belitung Timur, Statistik Daerah Belitung Timur 2015, http://belitungtimurkab.bps.go.id 
sex ratio sebesar 108, 52. Tercatat jumlah penduduk laki-laki sebanyak 60.903 jiwa dan penduduk perempuan sebanyak 56.123 jiwa. Penduduk Belitung Timur yang termasuk dalam usia produkstif (15-64 tahun) tahun 2014 berjumlah 80.850 jiwa. Sisanya sebanyak 36.176 jiwa tergolong dalam usia non produktif.

Dari data tersebut maka diperoleh ratio ketergantungan/ dependency ratio Belitung Timur adalah 45, yang dapat didefinisikan bahwa 100 orang usia produktif menanggung keberlangsungan 45 orang usia non produktif. Hal ini mencerminkan bahwa Belitung Timur sedang mengalami Bonus Demografi yang memberikan peluang yang lebih besar bagi Belitung Timur untuk meningkatkan perekonomian.

Pariwisata merupakan salah satu sektor andalan di Kabupaten Belitung Timur dengan melihat potensi yang ada seperti hamparan pasir putih, bebatuan granit dengan mozaik nan indah dan deburan air laut jernih dan terumbu karang merupakan daya tarik bagi wisatawan. Potensi lain juga datang dari objek wisata pantai antara lain Pantai Nyiur Melambai, Pantai Punai, Pantai Tanjung Kelumpang, Pantai Burung Mandi dan lainya. Belitung Timur memiliki potensi wisata dan budaya yang sangat indah, dan hal tersebut belum optimal pengelolaannya, walaupun perencanaan dan pengembangannya terus dilakukan, utamanya dengan mengkonsentrasikan kegiatan pariwisata berbasis budaya dan alam untuk mendukung peningkatan kunjungan wisata.

\section{Perbandingan Regional}

Jumlah penduduk Kabupaten Belitung Timur tahun 2014 mencapai 117.026 jiwa atau 9\% dari jumlah penduduk Provinsi Kepulauan Bangka Belitung. Jumlah ini merupakan populasi penduduk terkecil diantara 7 kabupaten/kota di Provinsi Kepulauan Bangka Belitung. Sedangkan populasi penduduk terbesar masih ditempati oleh Kabupaten Bangka dengan penduduknya sebesar 304.485 jiwa atau 23\%. Persentase perbandingan jumlah 
penduduk Provinsi Kepulauan Bangka Belitung tersebut sebagai tergambar pada gambar 2 berikut:

\section{Gambar 2}

\section{Jumlah Penduduk Provinsi Kepulauan Bangka Belitung \\ Menurut Kabupaten/KotaTahun 2014}

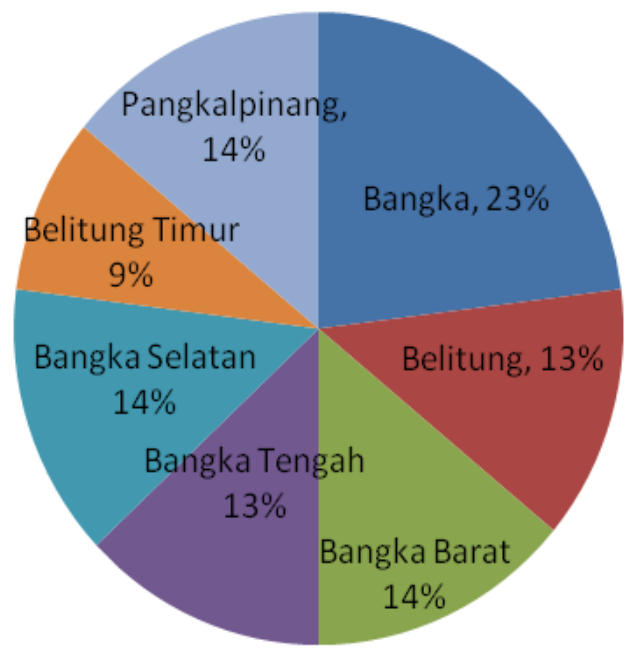

Sumber: Belitung Timur Dalam Angka 2015

Kabupaten Belitung Timur pada perbandingan regional masih menempati posisi yang cukup rendah di Provinsi Kepulauan Bangka Belitung. Kodisi tersebut sebagaimana tergambar pada data berikut:

1. Angka Indeks Pembangunan Manusia (IPM) Kabupaten Belitung Timur tahun mencapai 68,10, merupakan peringkat ke empat dari tujuh kabupaten/kota se-Propinsi Kepulauan Bangka Belitung. Angka ini termasuk dalam kategori capaian IPM sedang. Sedangkan pertumbuhan IPM adalah sebesar 0,57 persen, dengan rata-rata pertumbuhan selama empat tahun terakhir mencapai 1,17 persen. 
Tabel 1

Indeks Pembangunan Manusia (IPM) Kabupaten/Kota

Provinisi Kepulauan Bangka BelitungTahun 2013-2015

\begin{tabular}{|c|c|c|c|c|c|c|c|}
\hline \multirow{2}{*}{ Kode } & \multirow{2}{*}{ Kabupaten/ Kota } & \multicolumn{6}{|c|}{ IPM } \\
\hline & & 2010 & 2011 & 2012 & 2013 & 2014 & 2015 \\
\hline 1901 & Bangka & 66.41 & 67.37 & 67.99 & 69.34 & 69.79 & 70.03 \\
\hline 1902 & Belitung & 66.79 & 67.17 & 67.87 & 69.27 & 69.56 & 70.29 \\
\hline 1903 & Bangka Barat & 63.16 & 64.00 & 64.92 & 65.85 & 66.43 & 67.23 \\
\hline 1904 & Bangka Tengah & 65.10 & 66.09 & 66.88 & 67.67 & 68.09 & 68.66 \\
\hline 1905 & Bangka Selatan & 59.98 & 60.53 & 61.17 & 62.96 & 63.54 & 63.89 \\
\hline 1906 & Belitung Timur & 64.99 & 65.86 & 66.59 & 67.71 & 68.10 & 68.83 \\
\hline & Kota Pangkal & & & & & & \\
\hline & Pinang & 74.68 & 75.02 & 75.69 & 76.14 & 76.28 & 76.61 \\
\hline 1900 & $\begin{array}{l}\text { KEP. BANGKA } \\
\text { BELITUNG }\end{array}$ & 66.02 & 66.59 & 67.21 & 67.92 & 68.27 & 69.05 \\
\hline
\end{tabular}

Sumber : BPS Provinsi Kepulauan Bangka Belitung

2. Tingkat partisipasi angkatan kerja (TPAK) tahun 2014 sebesar 68,79 persen, artinya penduduk usia kerja atau penduduk berumur 15 tahun ke atas yang aktif secara ekonomi sebesar 68,79 persen. Tingkat Pengangguran Terbuka (TPT) sebesar 2,61 persen berarti dari 100 penduduk yang termasuk dalam angkatan kerja, kurang lebih terdapat 3 orang yang menganggur atau sedang mencari pekerjaan. Perbandingan Regional Ketenagakerjaan Kabupaten/Kota Propinsi Kepulauan Bangka Belitung Tahun 2014 sebagaimana terpapar pada tabel 2 berikut: 
Tabel 2

Perbandingan Regional Ketenagakerjaan Kabupaten/Kota

Propinsi Kepulauan Bangka Belitung

Tahun 2014

\begin{tabular}{lcc}
\hline \multicolumn{1}{c}{ Kabupaten /Kota } & TPAK & TPT \\
\hline Bangka & $\mathbf{( 2 )}$ & $\mathbf{( 3 )}$ \\
\hline Belitung & 61,65 & 4,26 \\
\hline Bangka Barat & 66,05 & 2,59 \\
\hline Bangka Tengah & 66,47 & 3,91 \\
\hline Bangka Selatan & 59,97 & 3,47 \\
\hline Belitung Timur & 63,47 & 1,64 \\
\hline Pangkalpinang & 63,42 & 2,20 \\
\hline Propinsi & 60,37 & 6,66 \\
\hline
\end{tabular}

Sumber: Belitung Timur Dalam Angka 2015

\section{J. Kebijakan Pemerintah Daerah dalam bidang pendidikan demi kesiapan MEA}

Peningkatan sumber daya manusia saat ini utamanya adalah melalui proses pendidikan. Melalui pendidikan diharapkan dapat terbentuk manusia yang berkualitas yang memiliki kemampuan menguasai ilmu pengetahuan dan teknologi yang diperlukan untuk mendukung pembangunan di berbagai bidang. Dengan demikian pendidikan merupakan cara untuk membangun manusia sebagai sumber daya pembangunan. Pada tahun 2014, berdasarkan data dari Dinas Pendidikan Kabupaten Belitung Timur, tercatat jumlah Sekolah Dasar (SD) sebanyak 104 unit, SMP sebanyak 22 unit, dan SMA/SMK sebanyak 13 unit, terdiri dari SMA sebanyak 7 unit, SMK 6 unit.

Sementara itu data pendidikan dari Departemen Agama Kabupaten Belitung Timur menunjukkan jumlah MI (Madrasah Ibtidaiyah) negeri 
sebanyak 1 unit, jumlah MTs (Madrasah Tsanawiyah) negeri 2 unit dan MA (Madrasah Aliyah) 1 unit. Tabel 3 berikut memaparkan data jumlah sekolah, murid, dan guru di kabupaten Belitung Timur:

Tabel 3

Jumlah Sekolah, Murid dan Guru (Negeri dan Swasta) di Kabupaten Belitung Timur 2012-2014

\begin{tabular}{|l|r|r|r|}
\hline \multicolumn{1}{|c|}{ Uraian } & \multicolumn{1}{c|}{$\mathbf{2 0 1 2}$} & \multicolumn{1}{c|}{$\mathbf{2 0 1 3}$} & \multicolumn{1}{c|}{$\mathbf{2 0 1 4}$} \\
\hline \multicolumn{1}{|c|}{$(\mathbf{1 )}$} & $\mathbf{( 2 )}$ & $\mathbf{( 3 )}$ & $\mathbf{( 4 )}$ \\
\hline Jumlah Sekolah & 104 & 104 & 104 \\
a. SD sederajat & 20 & 20 & 22 \\
b. SMP sederajat & 12 & 12 & 13 \\
c. SMA/SMK sederajat & 13380 & 15879 & 13928 \\
\hline Jumlah Murid & 4884 & 4563 & 5365 \\
a. SD sederajat & 3258 & 3320 & 3983 \\
b. SMP sederajat & 1072 & 883 & 1034 \\
c. SMA/SMK sederajat & 325 & 272 & 341 \\
\hline Jumlah Guru & 294 & 287 & 317 \\
a. SD sederajat & & & \\
b. SMP sederajat & & & \\
c. SMA/SMK sederajat & & & \\
\hline
\end{tabular}

Sumber: Belitung Timur Dalam Angka 2015

Angka Harapan Lama Sekolah (HLS) Kabupaten Belitung Timur tahun 2014 adalah sebesar 10,94 tahun. Nilai ini menunjukkan bahwa penduduk Kabupaten Belitung Timur yang berusia 7 tahun keatas diharapkan dapat bersekolah selama 10,94 tahun kedepan. Dan Ratarata Lama Sekolah (RLS) sebesar 7,89 tahun didefinisikan sebagai waktu yang dihabiskan oleh 
penduduk Belitung Timur untuk menjalani pendidikan formal adalah 7,89 tahun. Berikut tabel indikator pendidikan di Kabupaten Belitung Timur:

Tabel 4

Indikator Pendidikan di Belitung Timur, 2013-2014

\begin{tabular}{|l|l|l|}
\hline & $\mathbf{2 0 1 3}$ & $\mathbf{2 0 1 4}$ \\
\hline \multicolumn{1}{|c|}{$(\mathbf{1})$} & \multicolumn{1}{|c|}{$\mathbf{( 2 )}$} & \multicolumn{1}{|c|}{$(\mathbf{3})$} \\
\hline Angka Harapan Lama Sekolah (tahun) & 10,71 & 10,94 \\
\hline Rata-rata Lama Sekolah (tahun) & 7,83 & 7,89 \\
\hline
\end{tabular}

Sumber: Belitung Timur Dalam Angka 2015

Pendidikan menjadi modal utama mempersiapkan tenaga kerja yang dapat bersaing di ajang MEA dan benteng utama dalam mencegah perilaku menyimpang yang dapat merusak masa depan generasi tenaga kerja kompetitif. Wajib belajar (Wajar) 12 tahun menjadi bagian dari upaya untuk mencerdaskan kehidupan bangsa, dan meningkatkan kualitas manusia Indonesia seutuhnya. Pemerintah Kabupaten Belitung Timur mempunyai kewajiban membina dan mengembangkan pendidikan yang bermutu bagi warga masyarakat, sehingga terwujud pendidikan yang berkualitas; penyelenggaraan pendidikan merupakan tanggung jawab bersama antara Pemerintah, Pemerintah Propinsi, Pemerintah Daerah dan Masyarakat, sehingga mampu menjamin pemerataan kesempatan memperoleh pendidikan dalam rangka mengembangkan potensi anak didik/peserta didik melalui proses pembelajaran yang partisipatif, berkeadilan, tidak diskriminatif dengan menjunjung tinggi hak asasi manusia, nilai keagamaan, nilai kultural warga didik dan warga masyarakat.

1. Peraturan Daerah Kabupaten Belitung Timur Nomor 10 Tahun 2011 Tentang Sistem Penyelenggaraan Pendidikan 
Pendidikan adalah usaha sadar dan terencana untuk mewujudkan suasana belajar dan proses pembelajaran agar peserta didik secara aktif mengembangkan potensi dirinya untuk memiliki kekuatan spiritual keagamaan, pengendalian diri, kepribadian, kecerdasan, akhlak mulia, serta keterampilan yang diperlukan dirinya, diperlukan masyarakat, bangsa dan negara. Visi Pendidikan Daerah adalah terwujudnya pendidikan yang bermutu, dinamis, kreatif, inovatif untuk membentuk manusia yang cerdas, berbudaya dan berakhlak mulia. Program wajib belajar 12 tahun diharapkan dapat membangun pondasi yang baik bagi peserta pendidikan dalam memahami lingkungan dan peningkatan derajat pengetahuannya.

2. Peraturan Daerah Kabupaten Belitung Timur Nomor 6 Tahun 2014 Tentang Pendidikan Baca Tulis al-Qur'an

Pendidikan merupakan salah satu hak masyarakat, sehingga penyelenggaraan sistem pendidikan harus mampu menjamin pemerataan kesempatan pendidikan dan peningkatan mutu untuk melahirkan generasi yang beriman dan bertaqwa kepada Tuhan Yang Maha Esa, berahlak mulia, berilmu, cakap, kreatif, mandiri dan menjadi warga negara yang demokratris serta bertanggung jawab. Baca tulis al-Qur'an merupakan salah satu kewajiban bagi umat muslim, sehingga penyelenggaraan pendidikan baca tulis al-Qur'an bagi masyarakat dimaksudkan sebagai upaya strategis dalam rangka membangun dan membentuk manusia yang berahlak dan berwawasan Qur'ani. Sumber daya manusia dengan landasan keimanan dan agama yang kuat dapat menjadi modal bagus untuk pengembangan kualitas SDM di masa yang akan datang.

3. Peraturan Daerah Kabupaten Belitung Timur Nomor 6 Tahun 2011 Tentang Pengawasan dan Pengendalian Peredaran Minuman Beralkohol di Kabupaten Belitung Timur 
Minuman beralkohol memiliki dampak merusak yang tinggi, selain akan menyebabkan generasi muda kehilangan motivasi dalam berkompetisi dalam prestasi, juga berdampak buruk bagi kesehatan. Dalam rangka melindungi kesehatan, ketentraman dan ketertiban serta kehidupan sosial masyarakat dari akibat buruk konsumsi minuman beralkohol, perlu dilakukan pengawasan dan pengendalian terhadap peredaran minuman beralkohol. Semua peredaran minuman beralkohol tinggi tidak diperbolehkan lagi di area-area umum, hanya di area yang mengantongi izin. Hal ini merupakan bukti keterlibatan pemerintah daerah dalam melindungi remaja agar dapat berkontribusi positif dan meningkatkan kualitas Sumber Daya Manusia daerah.

\section{K. Tantangan Ketenaga Kerjaan di Kabupaten Belitung Timur}

Indikator ketenagakerjaan merupakan indikator penting dalam perencanaan dan evaluasi pembangunan baik ekonomi dan sosial. Pertumbuhan penduduk yang diikuti dengan peningkatan angkatan kerja akan memengaruhi pembangunan. Dengan meningkatnya penduduk usia kerja yang tidak terserap dalam perekonomian, maka akan menyebabkan pengangguran yang pada akhirnya dapat menimbulkan masalah sosial. Dari total penduduk Kabupaten Belitung Timur pada tahun 2014, 51, 12 persen berada pada usia kerja (15 tahun keatas).

TPAK tahun 2014 adalah 68, 79 persen, artinya penduduk berumur 15 tahun ke atas di Kabupaten Belitung Timur yang bekerja adalah sebanyak 68,79 persen. TPT di Belitung Timur sempat turun di tahun 2013, namun meningkat kembali di tahun 2014. TPT tercatat sebesar 2,61 persen, meningkat dari 2,20 persen di tahun sebelumnya. Ini berarti pada tahun 2014 dari 100 penduduk yang termasuk dalam angkatan kerja kurang lebih terdapat 3 orang yang menganggur. Jumlah Penduduk Usia 15 tahun keatas Menurut Jenis Kegiatan, Kabupaten Belitung Timur, 2014 sebagaimana tergambar pada tabel 5 berikut: 
Tabel 5

Jumlah Penduduk Usia 15 tahun keatas Menurut Jenis Kegiatan,

Kabupaten Belitung Timur, 2014

\begin{tabular}{|c|c|c|}
\hline & & 2014 \\
\hline (1) & (2) & (3) \\
\hline \multirow[t]{2}{*}{ Angkatan Kerja } & Bekerja & 58259 \\
\hline & Pengangguran Terbuka* & 1562 \\
\hline \multicolumn{2}{|c|}{ Bukan Angkatan Kerja } & 27140 \\
\hline \multicolumn{2}{|c|}{ Total Penduduk 15+ } & 86961 \\
\hline
\end{tabular}

Sumber: Sakernas Agustus 2014

Catatan: 1. Mencari Pekerjaan

2. Mempersiapkan Usaha

3. Merasa tidak mungkin mendapatkan pekerjaan

4. Sudah punya pekerjaan tapi belum mulai bekerja

Tantangan ketenaga kerjaan untuk mempersiapkan SDM menuju MEA datang dari pernikahan dini. Menurut data Badan Pusat Statistik Bangka Belitung yang bersumber pada Sensus penduduk tahun 2010, penduduk kabupaten Belitung Timur kelompok umur di bawah 15 tahun yang berstatus kawin berjumlah 18 Jiwa. Dari jumlah tersebut tidak ada yang berstatus cerai hidup. Sementara itu, penduduk dalam kelompok umur 15-19 tahun dengan status kawin berjumlah 972 jiwa, dan dari jumlah tersebut 23 jiwa sudah berstatus cerai hidup. Dari jumlah kedua kategori tersebut, sebanyak 272 jiwa sebagai menantu (artinya jumlah tersebut masih tinggal bersama dengan mertua atau belum memiliki tempat tinggal atau rumah sendiri). Berdasar data di bawah ini, tidak ada yang melakukan pernikahan di bawah usia 15 tahun berakhir dengan perceraian. Sementara itu, 2,37\% pernikahan dalam kelompok umur 15-19 tahun berakhir dengan perceraian. Dari kategori umur di bawah 15 tahun yang melakukan pernikahan 22,22\% masih menggantungkan 
hidupnya pada orang tua, atau masih tinggal bersama mertua, dan 28,27\% dari yang menikah pada kelompok umur 15-19 tahun masih tinggal bersama dengan mertua. Data tersebut sebagaimana tertuang dalam tabel 6 berikut:

Tabel 6

Pernikahan Dini di Kabupaten Belitung Timur

\begin{tabular}{lccccccc}
\hline Kab./kota & $\begin{array}{c}\text { Kelompok } \\
\text { Umur }\end{array}$ & Kawin & $\begin{array}{c}\text { Cerai } \\
\text { Hidup }\end{array}$ & $\%$ & $\begin{array}{c}\text { Keluarga } \\
\text { utuh }\end{array}$ & Menantu & \% \\
\hline $\begin{array}{l}\text { Belitung } \\
\text { Timur }\end{array}$ & $10-14$ & 18 & 0 & 0.00 & 18 & 4 & 22.22 \\
& $15-19$ & 972 & 23 & 2.37 & 948 & 268 & 28.27 \\
\hline \multicolumn{1}{l}{ Jumlah } & & $\mathbf{9 9 0}$ & $\mathbf{2 3}$ & $\mathbf{2 . 3 7}$ & $\mathbf{9 6 6}$ & $\mathbf{2 7 2}$ & $\mathbf{2 8 , \mathbf { 1 6 }}$ \\
\hline \multicolumn{2}{l}{ Sumber: Sensus Penduduk 2010 }
\end{tabular}

Pendidikan rendah juga menjadi salah satu penyebab pemahaman masyarakat salah dalam memandang pernikahan pada usia dini. Banyak orang tua karena rendahnya pendidikan, tidak mempunyai visi bagi masa depan anaknya. Sehingga anak tidak mempunyai arah dan konsep untuk mempersiapkan masa depannya menjadi lebih mapan dan matang dalam menggapai masa depan. Begitupun dengan anak, karena tidak memiliki pendidikan yang tinggi (setara Sekolah Menengah Atas/SMA), membuat anak tidak mempunyai cita-cita yang besar untuk mempersiapkan hari depan mereka. Ironisnya, ada kebanggaan di sebagian orang tua, apabila anak-anak mereka menikah di usia muda. Ini adalah karena pemahaman mereka yang rendah dalam memandang masa depan anak. Karena itulah rendahnya tingkat pendidikan menjadi salah satu penyebab terjadinya pernikahan dini di kalangan remaja. 
Dampak pernikahan dini dari segi kesehatan menurut Supeni ${ }^{9}$ di antaranya risiko tinggi (kematian) saat melahirkan dan kelahiran bayi prematur, berdampak pada angka kematian ibu (AKI). Menurut M. Ali10, secara biologis remaja putri belum siap menjadi seorang ibu, belum siap menyandang status seorang ibu. Masa remaja yang gemilang dan penuh harapan harus terhenti dengan mengurus anak dan suami dengan persoalan rumah tangga. Secara ekonomi pasangan muda belum matang dan mapan dalam membangun ekonomi rumah tangga. Banyak di antara mereka yang masih sangat bergantung dengan orang tua, dan tinggal dengan orang tua. Kondisi ini dipahami berdasarkan data sensus penduduk tahun 2010, dari 966 penduduk yang melakukan pernikahan dini dan keluarganya masih utuh, sebesar 28,2\% masih menggantungkan hidup pada orang tuanya. Remaja yang terlbat pernikahan dini tidak dapat dipersiapkan menjadi tenaga kerja dengan tingkat ketrampilan cukup tinggi, karena desakan pemenuhan kebutuhan dasar.

Selain pernikahan dini, polemik kenakalan remaja seperti konsumsi zat adiktif, banyak dilakukan remaja usia 14-18 tahun yang mengkonsumsi aibon, komik dan oplosan. Perbuatan menyimpang ini disebabkan ajang coba-coba remaja yang terikut dengan lingkungannya. Pemantauan sulit dilakukan karena dilaksanakan dirumah dalam keadaan kosong, dan juga dilakukan di tempat yang jauh dari pemukiman. Hal ini ikut menyulitkan pemberian efek jera perilaku menyimpang jenis ini. Kemerosotan moral juga menjadi salah satu pemicu terjadinya perilaku menyimpang. Pada usia remaja ini, seharusnya dipersiapkan sebagai calon tenaga kerja yang produktif, namun tidak dapat dilaksanakan karena di pengaruhi oleh kenakalan remaja.

\footnotetext{
${ }^{9}$ Utusan Dinas Kesehatan Kabupaten Belitung Timur, ibid.

${ }^{10}$ Utusan Kementerian Agama Kabupaten Belitung Timur, ibid.
} 


\section{Kesimpulan}

Berdasarkan uraikan pada bab-bab sebelumnya dapat disimpulkan sebagai berikut:

1. Dua penyebab utama dari rendahnya pemanfaatan sumber daya manusia adalah karena tingkat pengangguran penuh dan tingkat pengangguran terselubung yang terlalu tinggi dan terus melonjak. Pengangguran penuh atau terbuka yakni terdiri dari orang-orang yang sebenarnya mampu dan ingin bekerja, akan tetapi tidak mendapatkan lapangan pekerjaan sama sekali.

2. Pemerintah Daerah Kabupaten Belitung Timur belum banyak mengeluarkan kebiajakn ketenaga kerjaan, khususnya dalam menyiapkan sumberdaya manusianya dalam menghadapi Masyarakat Ekonomi ASEAN atau pasar bebas ASEAN.

3. bahwa meningkatnya pengangguran tenaga terdidik merupakan gabungan beberapa penyebab yang sekaligus merupakan tantangan ketenagakerjaan di Belitung Timur:

a. Pertama, ketidakcocokkan antara karakteristik lulusan baru yang memasuki dunia kerja (sisi penawaran tenaga kerja) dan kesempatan kerja yang tersedia (sisi permintaan tenaga kerja). Ketidakcocokan ini mungkin bersifat geografis, jenis pekerjaan, orientasi status, atau masalah keahlian khusus. Memang juga bahwa tidak setiap lulusan langsung mencari kerja.

b. kedua, semakin terdidik seseorang, semakin besar harapannya pada jenis pekerjaan yang aman. Golongan ini menilai tinggi pekerjaan yang stabil daripada pekerjaan yang beresiko tinggi sehingga lebih suka bekerja pada perusahaan yang lebih besar daripada membuka usaha sendiri. Hal ini diperkuat oleh hasil studi Clignet (1980), yang menemukan gejala meningkatnya 
pengangguran terdidik di Indonesia, antara lain disebabkan adanya keinginan memilih pekerjaan yang aman dari resiko. Dengan demikian angkatan kerja terdidik lebih suka memilih menganggur daripada mendapat pekerjaan yang tidak sesuai dengan keinginan mereka.

c. Ketiga, terbatasnya daya serap tenaga kerja sektor formal, sementara angkatan kerja terdidik cenderung memasuki sektor formal yang kurang beresiko. Hal ini menimbulkan tekanan penawaran, yaitu tenaga kerja terdidik yang jumlahnya cukup besar memberi tekanan yang kuat terhadap kesempatan kerja di sektor formal yang jumlahnya relatif kecil.

d. Keempat, belum efisiennya fungsi pasar kerja. Di samping faktor kesulitan memperoleh lapangan kerja, arus informasi tenaga kerja yang tidak sempurna dan tidak lancar menyebabkan banyak angkatan kerja bekerja di luar bidangnya. Denga begitu ada banyak hal yang menyebabkan peningkatan pengangguran terdidik terutama dari sebab faktor gengsi pendidikan menyebabkan lulusan akademi atau universitas memilih menganggur, masalah skil lulusan serta sempitnya lowongan pekerjaan sektor formal. 
Agus Triyono

\section{DAFTAR PUSTAKA}

Badan Pusat Statistik Kabupaten Belitung Timur, Statistik Daerah Belitung Timur 2015, http://belitungtimurkab.bps.go.id

Data dari Website kek.go.id/kawasan/tanjung-kelayang, diakses 27 November 2017.

Data Dasar Kabupaten Belitung Timur Tahun 2013 badan Perencanaan Pembangunan Daerah Kabupaten Belitung Timur Tahun 2013

Djojohadikusumo, Sumitro, Dasar Teori Ekonomi Pertumbuhan dan Pembangunan, Jakarta : Bagian Penerbitan : LP3ES, 1987.

http://www.academia.edu/9060383/masyarakat_ekonomi_ASEAN_2015_MEA_2015, diakses tanggal 21 November 2017.

http://belitungtimurkab.bps.go.id/belitungtimurdalamangka 2014

Keadaan Angkatan Kerja di Indonesia/Labor Force Situation in Indonesia, Badan Pusat Statistik, 2013.

Sumarsono, Sonny, Ekonomi Manajemen Sumber Daya Manusia dan Ketenaga kerjaan, Jogyakarta : Graha Ilmu, 2003.

Utusan Dinas Kesehatan Kabupaten Belitung Timur.

Utusan Kementerian Agama Kabupaten Belitung Timur. 